TM-1455

2281.000

\title{
Single Wire Drift Chamber Design
}

\author{
J. Krider \\ Fermi National Accelerator Laboratory \\ P.O. Box 500 \\ Batavia, IL 60510 USA
}

March 30, 1987 
30 Merch 67

\section{Single Wire Drift Chamber Design \\ J. krider \\ Research Facilities Department}

This report summarizes the design and prototupe tests of shole shite drift chambers ta be used in Fermilat test beam lines The god is to build simple. reliable detectore which require a mimum of electronics spotial resolution should match the 300 un ros resolution of the inm proportional chambers that they will replace. The detectors wit? De lesd in beams with partiche rates up to $20 \mathrm{KHz}$. Single track effictency should be at least 998 . The first applicotion will be in the MT beamline. which has been designed for calitration of COF detectors. A set of four $x-y$ modules will be used to track and megsure the mamentum of beam pirticles.

MECHANICAL DESCRIPTION

One chanter module consists of four independent single wire drift cells, each with an active area of $102 \mathrm{~mm}$ by $102 \mathrm{~mm}$. Two cens hove Wertical wires ta measure a horizontal courdinete, and the other twa cells howe horizontal wires to measure a vertical coordinate lone cell has its anode affet 203 mm to one side of the center. while the ather cen measuring the same coudinate has its ande of fet $20.3 \mathrm{~mm}$ to the other side. This resolves the left-right ambiguties and provides a constint montor of the electron drift velocity.

The various layers of anodes, cathodes, cell isolation folls, and spocers are stacked an aligment pins mounted an a 12.7 mm thick alurinum tase plate. Locations of individual anode and cathode planes are maintained to \pm 25 um by the pins. All anode plines are interchargeatle. with the absolute position accuracy of all anode wires being \pm 125 um with resect to the bose plate centerline

There is no gas seal between logers within the detector stack A remulable sluminum box cover bolts to the base plate and has an j-ring gos seal. High voltages and anode signals pass through the base plate using connectors sealed with eposy. Mylar beam windows of 125 um thickress cover $102 \mathrm{~mm}$ by $102 \mathrm{~mm}$ holes in the upstream and downetream aluminum box faces. The air leak rate of the prototupe asembily was megured to be 
$250 \mathrm{co} / \mathrm{hr}$ at $20 \mathrm{peig}$, which corresponds to $5 \mathrm{co} / \mathrm{hr}$ at the likely aperating pressure of 10 inch of water.

A cell consists of an anode plane centered in a $95 \mathrm{~mm}$ total gap between a pair of field shaping cathode planes. A $15 \mu \mathrm{m}$ thick grounded glummurin ion located $9.5 \mathrm{~mm}$ to the outside of each cothode to electrostationly isolate that cell from other cells in the chanter. The crosection of an inside edge of one cell is shown in Figure 1. The vorious layers have difierent incide dimensions in order to make the high voltage breakdown path acrose the insuator surfaces longer than the breakdown path through the gis

Each arode plane is a single sided printed circut with the lagut showh in Figure 2. It has on 65 um diameter beryllium copper field wite at ether edge of the active area. These field wires are operated at the same fotential ge the nearest cothode plane field wires in order to improve the linearity of the drift field near the cell boundaries. A single 25 um dianeter gold plated tungsten anode mire is locoted 203 mm to the left of center. A schematic of the circuitry inside the box for one cell is shown in Figure 4 . The ande wire is operited at a positive high voltoge The output signal is decoupled from the high voltage with a 10 nF $7.5 k 4$ agocitor. \& $1.0 \mathrm{H}$ resistar in series with the power supply limits the peak charging curent to the wire.

The cathode printed circuit layout is shown in Figure 3 . The board has solder pads for 51 field shaphn wires cathode wires are 85 um diameter berylium copper spaced $203 \mathrm{~mm}$ apart. A resistor diwder network on the board supplies the required potential distribution The voltage dinder uses two $100 \mathrm{Mg} / \mathrm{T} / \mathrm{watt} 1 \mathrm{~s}$ metal film resistors in series per field voltage increment. For a drift fietd gradient of 1000 Vom, the voltage across each resistor is $100 \mathrm{~V}$. The diwder current is $100 \mathrm{kA}$, which is 10,000 times the awerage current draw of the chamber in a $20 \mathrm{KHz}$ beam. The five field wires nearest to the anode are isolated from the divider by $100 \mathrm{Ma}$ series resistors to limit the discharge current from the decoupling capacitor in the event of a high voltage breakdown.

\section{ELECTFONICS}

The chamber amplifier/discrminator used for the frototupe etudies was designed at Indiana University in 1975 . Figure 5 shows the 
circut schematic for the 16 chanel cord. The input impedance is $570 \Omega$ The circut uses three stages of ECL 10116 diferential recelvers, which are of coupled in series for an overall gain of approsimately 750 . The infut of est of each chamel is trimmed with a potentioneter The inputs are protected from large pulses ty diodes. The inputs of three chanels use the three receivers of one 10 for the lowest uatage amplification stage Separate lcs are used for intomediate and high level amplification to mimmize stray feodtack As the input thresold is lowered to zera, the autput goes through the transition from low to high state without gecillation. The sensitivity of input threshold to power supply voltage te $05 \mathrm{HA} / \mathrm{l}$. The temperature coefficient of the threshold $1 \mathrm{~s} 40 \mathrm{HA} / \mathrm{C}$. A new four channel FC buand is being prepared.

Time slewing of the amplifier was measured with a pulse generator and a series of attenuators. The amplifier was set to a threshold of $4.0 \mu \mathrm{H}$, and the input to output delay was measured for diferent amplitude input pulses. Figure 6 shows that the variation in delay, or time sewing. is $7 \mathrm{ne}$ for an mput range of 2 to 20 times threshold. The computes to a drift postion measurement error of $450 \mathrm{fm}$ in a chamber Using a $50 \%$ argon - $50 \%$ ethane gas mikture and a boo Wom drift field However, this error winl be much smaller in practice, because the spread in chamber pulse heights will be only a factor of two.

EFEETS OF CHELIMG ON TIME RESOLUTION

Measurements of amplifier time slewing were also made using chamber eignals from a Ru 106 source. The gas mixture was $90 \%$ argon $10 \%$ carbon diovide. The amplifier output was split into two paths. Ine path went directly to a discriminator to generate a Toc start signal. The discriminator threshoid of $50 \mathrm{~m}$ was anly 68 of the maximum pulse height, so it accounted for a sman fraction of the slewing, which was caused by slow risetimes The other amplifier output traveled through Either $130 \mathrm{ft}$ or $395 \mathrm{ft}$ of RG $10 \mathrm{~s}$ twinax catle before generating the TOC stop. The time distributions are shown in Figure $7 \mathrm{a}$, with the chamber operating at the edge of ts high voitage efficiency plateau, and in Figure 76,100 onto the efficiency plateau. For 130 ft of cable the time slewing is 25 ne FWHM at the edge of the plateau and 6.3 ns FWHM 100 onto the plateau. For 395 ft of catle the results are 16 ne and 4.8 ns. Time slewing 
is smaller whth the longer catile, tecalde the coble attenuates the leading edge of the figter nsetime signals more strongig. thus tunching the nsetme spectrum ine production system will use Thist-n-Flat cable with the longest run to signal repesters being 150 it. The oble has a risetime companate to the 395 ft of twinax used in the atone megurements.

The risetimes to the $\mathrm{ECL}$ crosedver voltage were measured to be 15 ns for 350 ft of twinas, 7 ne for $100 \mathrm{ft}$ of Thist-n-Flat as shown in Figure 6.21 he for 200 it of Twist-n-flot, and 40 ns for $300 \mathrm{ft}$ of

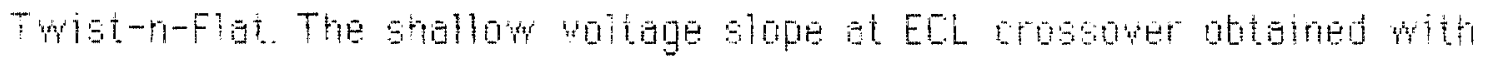
long cothes mokes the system timing more sensitive to noise Figure 9 presents an example of the amount of time messurement emor introduced by 100 mo $a-p$ of diferential noise as a function of Twist-n-flat catie length 15 the of drift lime corresponds to atout 1 mm of drift distance. Fholographe of chamber signals at the end of $100 \mathrm{ft}$ of Twist-n-Flat are enown in Figure 100 for a Ru106 source at the plateau edge (1517 y) and $100 \mathrm{~V}$ onta the plateat, and in Figure 100 for Fe5s signals at the same high voltoges

\section{CHAMEER PERFORMANCE}

The chamber gain as a function of high voltage was measured by varying the amplifier threshold and determining the corresponding ande high woltage which produced 50 of eficiency. Efficiency was measured with respect to tracke through a par of scintillation counters Figure 11 shows the lest setup. The gas mixture was $50 \%$ argon - $50 \%$ ethene. Results are fresented in Figure 12 for the threshold ronge of 1 to $3 \mu \mathrm{A}$. The slope is approkimately a factor of two gan change per $90 \mathrm{v}$.

Figure 13 shows typical high voltage efficiency and anode shgles count rote plateaus for 508 argon - 508 ethane and an amplifier thresond of 20 H. The efficiency rises from zero to maximum with about 200 change in the high voltage. Using the chamber gain factor getermined atove, this suggests that the chamber puse height spectrum for Fulob has a full width af atout a factor of five, i.e, the maximum pules height is five times the minimum pulse height. The eficiency tises from $10 \%$ to 908 in $120 \mathrm{~V}$, a spread of 23 in fulse height. The spectrum has a narrowar width for mimimum ionizing beam trocks. 
The platedus of three different cells were studiei using $50 \%$ argan - $50 \%$ ethane and a 20 uA threshold. For Ru 106 tracke passing olose to each anode the $50 \%$ efficiency point varies by only 6 . Based on this measurement all four cells within a module will be operoted at the same anode high voltage from a single power supply. The shit in plateat was studed for a $6 \mathrm{~cm}$ drift (7 cm is the maximum puselule) compared to esentially zero drift. For the two cells with 2 mo field wire pitch the Eo\% officheng pont shifted upward by an average of $20 y$, indicating a $105 \mathrm{~s}$ at atout $15 \%$ of the primary electrons. For the third cen, which was modified to have 4 mm field wire pitch. the plateau shifted $55 \mathrm{y}$, indicating $10 \mathrm{se}$ of about $35 \%$ of the primary electrons. For this reason 20 mm field wire pitch will be used in the production chambers

Figure 14 shows the drift velocity in $50 \%$ argon - 50 ethane as a function of the drift field. Drift velocity saturation sets in at atout 450 Vom; however, the velocity continues to increase gradully with

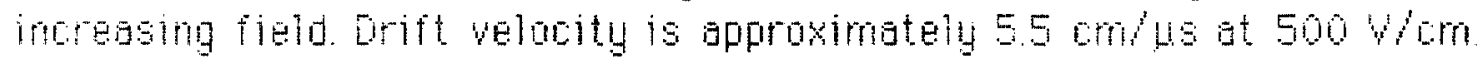
The production chambers will operate with a drift field of approximately $1000 \% \mathrm{rm}$

A typical drift time spectrum for cosmic roy tracks using a gas misture of $90 \%$ argan - $10 \%$ corton diaside is shown in Figure 15; the drift field is $570 \% / \mathrm{cm}$. The average drift velocity is $20 \mathrm{~cm} / 4 \mathrm{~s}$.

The linearity of drift velocity in the vicinity of an anode wite wos studied with cosmic rays by comparing the messured drift time in Eell 2 to the predicted drift time based on the messured drift times in cens 1 and 3 . The cell 2 anode is on the opposite side of the detector centerline from the cell 1 and 3 anodes; therefore, most tracke near anode 2 are much forther from anodes 1 and 3 and are in the linear region of those cells soster plats were made for the measured cell 2 drift time ve. the expected drift time colculated from the averge of the drift times in cells 1 and 3 . Figure 16 is for $50 \%$ argon $-50 \%$ ethane at $770 \mathrm{~W} / \mathrm{cm}$, while Figure 17 is for $90 \%$ argan - $10 \%$ corbon dioxide at 570 /cm. The segtering of tackgraund points is caused by left-tight ambiguities which the andysis program is not sophisticated enough to resolve correctly. The argon - ethane mixture clearly has much tetter linearity. Argon - carbon Goxide produces nonlinearity over a region of at least \pm 1 cm around the anode wire argon - ethane will be used in the production chambers.

Time resolution studies were done with both of the areviously 
mentioned ges mixtures. The time resolution is presented in the figures as the difference between the measured drift time for cell 2 and the calcuided drift time for cell 2 using measured orift times from cells 1 and 3 . These resulting arift time "error" distributions include bath the emor from cell 2 and the error from the calculated arift time Let oicell) be the rme negsurement error fer cell. The rms error of the calculated drift time is then ofcelly/ $\sqrt{2}$, shce the calculation inolves the average of two uncorrelated messurements. The oftotal of the detributions in the figures is the sum in quadrature of ofent and ofeen $/ \sqrt{2}$. Thus ofcen $=$ $0.820(t a t a 1)$.

Cosmic ray data for the entire active area of the detector using $50 \%$ argon - $50 \%$ ethane are presented in Figure 18 . The horizontal scale is 1.38 ne/ bin. The FWHM of this distribution is:

(16 bins)(2 ToC counts/tin)(35 um/ count) $=1120 \mu \mathrm{m}$

The global resolution per cen is then $0=390$ um The value shond improve for beam tracke, which are all nearly normal to the celle. A smilar coemic ray messurement with $90 \%$ argon - $10 \%$ carbon dianide is shown in figure 19. It has a long tail baused by the nonlines drift velocity. The harizontal sogle $182.5 \mathrm{~ns} / \mathrm{bin}$

Another resolution megsurement using the argon - carton dioxide mixture and a well collimated Ru 106 source, and requiring that the analyzed events all have cell 2 in the single TDC count 1190 , is shown in Figure 20 . The horizontal scale is 12.5 ns/tin. This localized megsurement yields a resolution per cell of $360 \mu m$ but to take advantage of this recolution, a correction would have to be applied for the variation in drift welocity acrose the cell

CHAMEER GAP STUOY

When the chamber aperates with a nom-saturiating gain, the arnde pulse reetime is equal to the spread in drift times of the electrons from the intial ionization track. The following assumptions were used to produce a simplified model of the relative drift times from diferent prints along the jonization track (1) the track is nombl to the chamber, (2) the drift path is parallel to the midplane of the chamber until the last 
5 mon of cell length from the anode, at which foint the electron turne abrupty toward the anode, and (3) the drift velocity is constant at 5 cmips. The resulting drift time distribution predicted by this model is presented in Figure 21. For the chamber described in the report. with an anode to cathode gap of $5 \mathrm{~mm}$, the electrons arrive at the anode oyer pertog of $42 n \mathrm{~ns}$

When the chamber is aperating at the edge of its high voltage offeiencu plateau for a given particle, ionization must be collected from the entire \pm 5 mm path length in order to saturate the amplifer gutput. The amplifier has a linear gain response for input signals betwen zero and 2 LiA, and tupically operates with a threshold of 2 H. Thus a pulse with a nestme of 42 ns is produced. If the chamber signal is incteased by a factor of twa either by raising the high yol age go y or ty having a more etrongly ionizing incident particle, then the amplifier will saturate with the charge collected from the central \pm 25 mm the shortest drift detance) and will have a risetime of only 12 ns.

In the case of Ru 106, which produces trocks with a total spreat of $5 x$ in primary ianization, the madel predicts a time spread of 40 ns iul width at the edge of the platesu or 10 ns full width 100 y anto the plateau. These predicted values are close to the messured values in Figures $7 \mathrm{a}$ and 70 , with the longer measured tails protabing being produced by inclined tracks.

For a $10 \mathrm{~mm}$ lang minimum ionizing track the average number of primary electrons produced is 30 , so the pulse height distribution win have an rms width of 168 . Under these conditions the model predicts a time spread of 60 ns me at the platean edge or 3.5 he 100 y onto the plateat Figure 22 shows the calculated time spread as a function of the anoue to cathode gap, when the chamber is operating 100 y anto the platesu a gap of 95 mm has been chosen. with the time slewing condtion setting the upper limit, and general ease of mechancal construction setthg the lower limit. The chamber will operate $100 \mathrm{~V}$ onto the plateau.

The contritutions to owerail chamber resolution include (1) gas diffusion, (2) the spread in drift path length described above, and 3 ) efectronice the slewing. Gas difusion contributes 260 um rns for the masmum drift of $7 \mathrm{~cm}$, or 140 um ms form a tupical $2 \mathrm{~cm}$ drift. ${ }^{2}$ The drift peth iength variation contributes $3.5 \mathrm{~ns}=190 \mu \mathrm{m}$ ms. Amplifier chang contributes 3.7 ns $=200$ um me. When these factors are added 
In quadoture the averall resolution is predicted to be 360 um for a 7 ch urift or 310 um for a $2 \mathrm{~cm}$ drift. The measured yolues for cosmo rage are consistent with these predictions. 


\section{REFEREHEES}

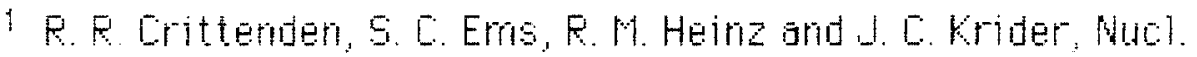

netr and Meth 165 (1961)75-79.

2 A Fiesert and F. Sall, CEFN 64-06 (1964) 


\section{LIST OF FIGURES}

1. Crossection of the edge of a cell

2. Anode printed circuit

3. Cathode printed circuit

4. Circuit diagram for one cell

5. Chamber amplifier schematic

6. Amplifier time slewing

7a. Time slewing for chamber signals at the plateau edge

7b. Time slewing for chamber signals $100 \mathrm{~V}$ onto the plateau

8. ECL signals after $100 \mathrm{ft}$ of Twist-n-Flat cable

9. Drift error caused by $100 \mathrm{mV}$ of noise as a function of cable length

10a. Ru 106 signals after $100 \mathrm{ft}$ of Twist-n-Flat cable - at the edge of and $100 \mathrm{~V}$ onto the plateau

10b. Fe55 signals after $100 \mathrm{ft}$ of Twist-n-Flat cable - at the edge of and $100 \mathrm{~V}$ onto the plateau

11. Chamber test setup

12. Chamber gain as a function of high voltage

13. Typical singles rate and efficiency plateaus as a function of high voltage

14. Drift velocity in $50 \%$ argon - $50 \%$ ethane as a function of field

15. Cosmic ray drift time spectrum for an entire cell

16. Drift velocity measurement setup

17. Drift velocity linearity in $50 \%$ argon - $50 \%$ ethane

18. Drift velocity linearity in $90 \%$ argon - $10 \%$ carbon dioxide

19. Global time resolution for cosmic rays in argon - ethane

20. Global time resolution for cosmic rays in argon - carbon dioxide

21. Time resolution for Ru 106 tracks at one drift distance in argon

- carbon dioxide

22. Electron drift time spread vs. anode to cathode gap 
Figure 1. Crossection of the edge of a cell

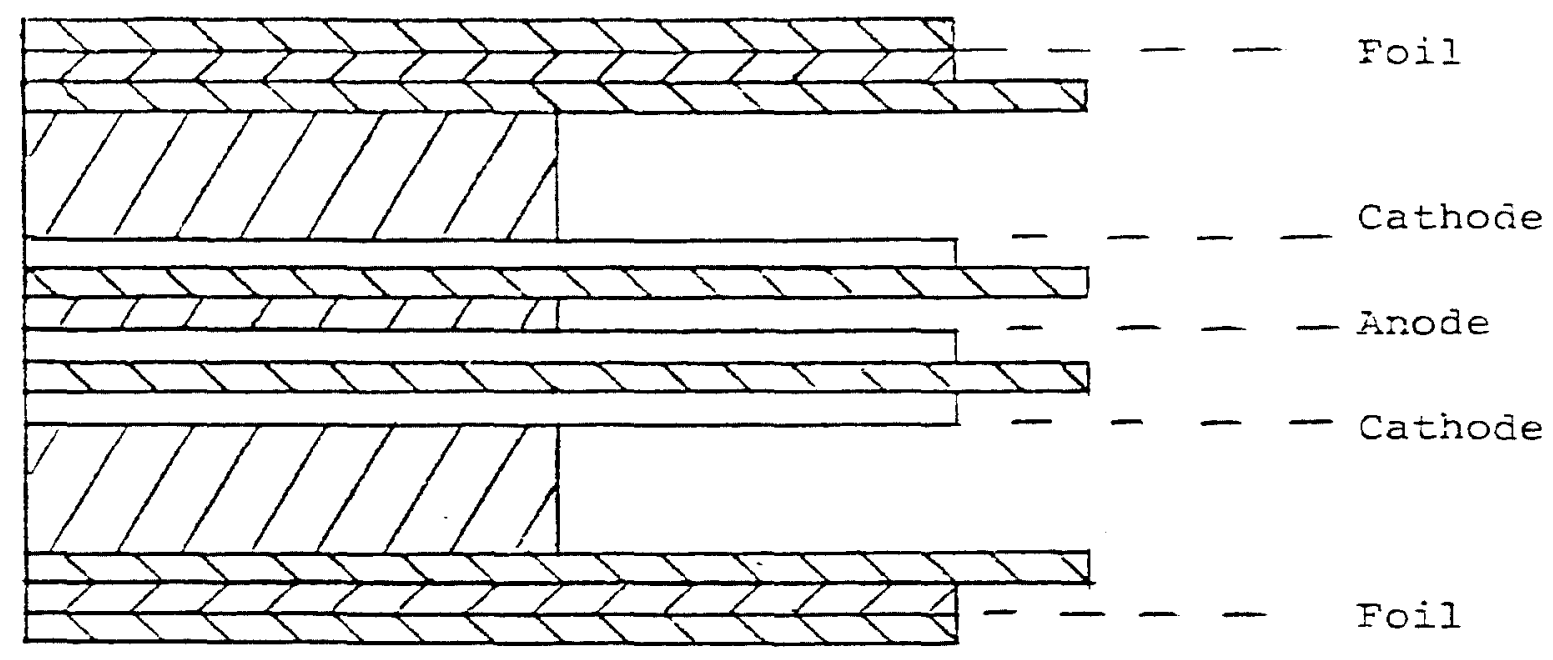

2.000 inches. 
Figure 2. Anode printed circuit

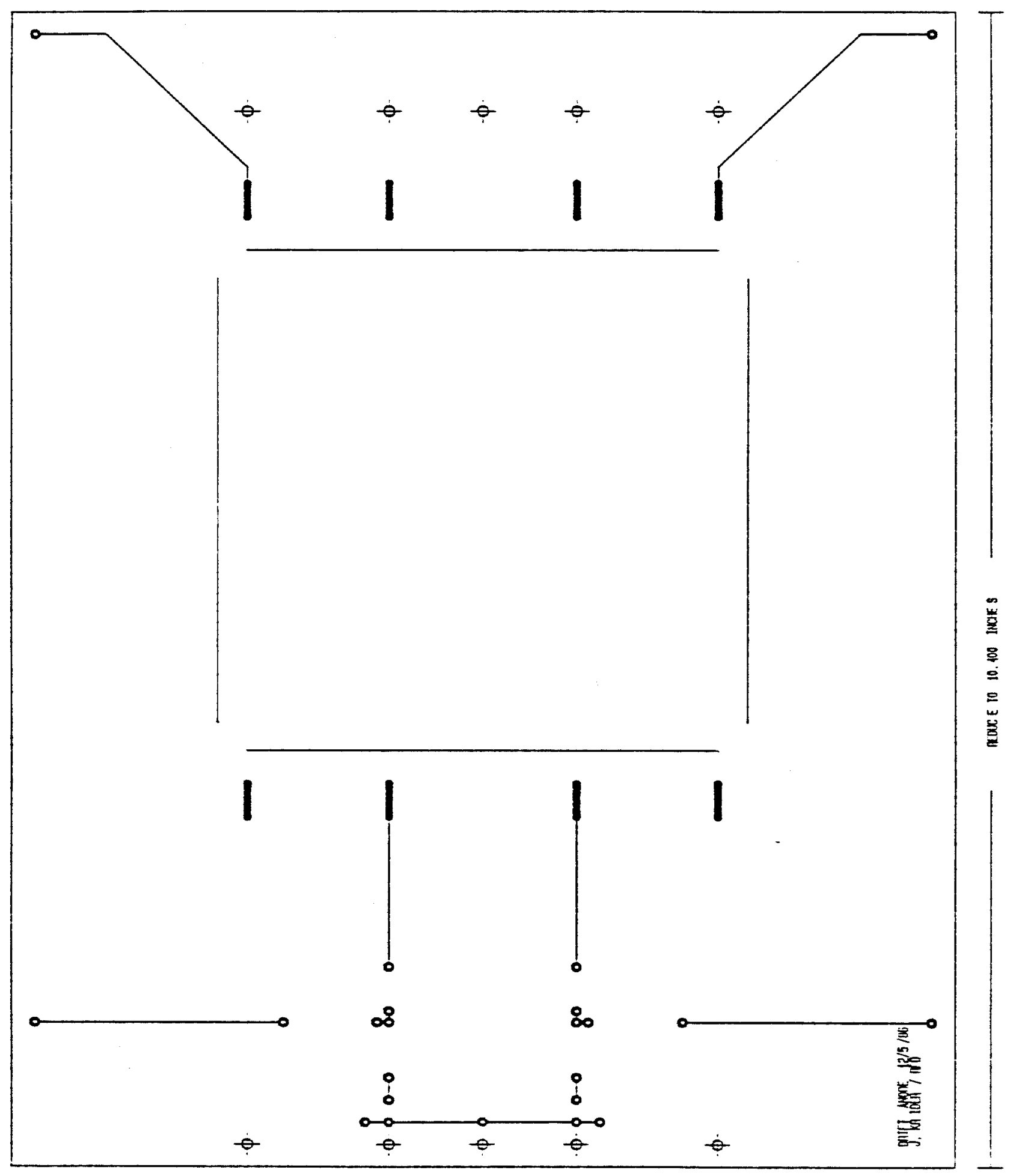


Figure 3. Cathode printed circuit

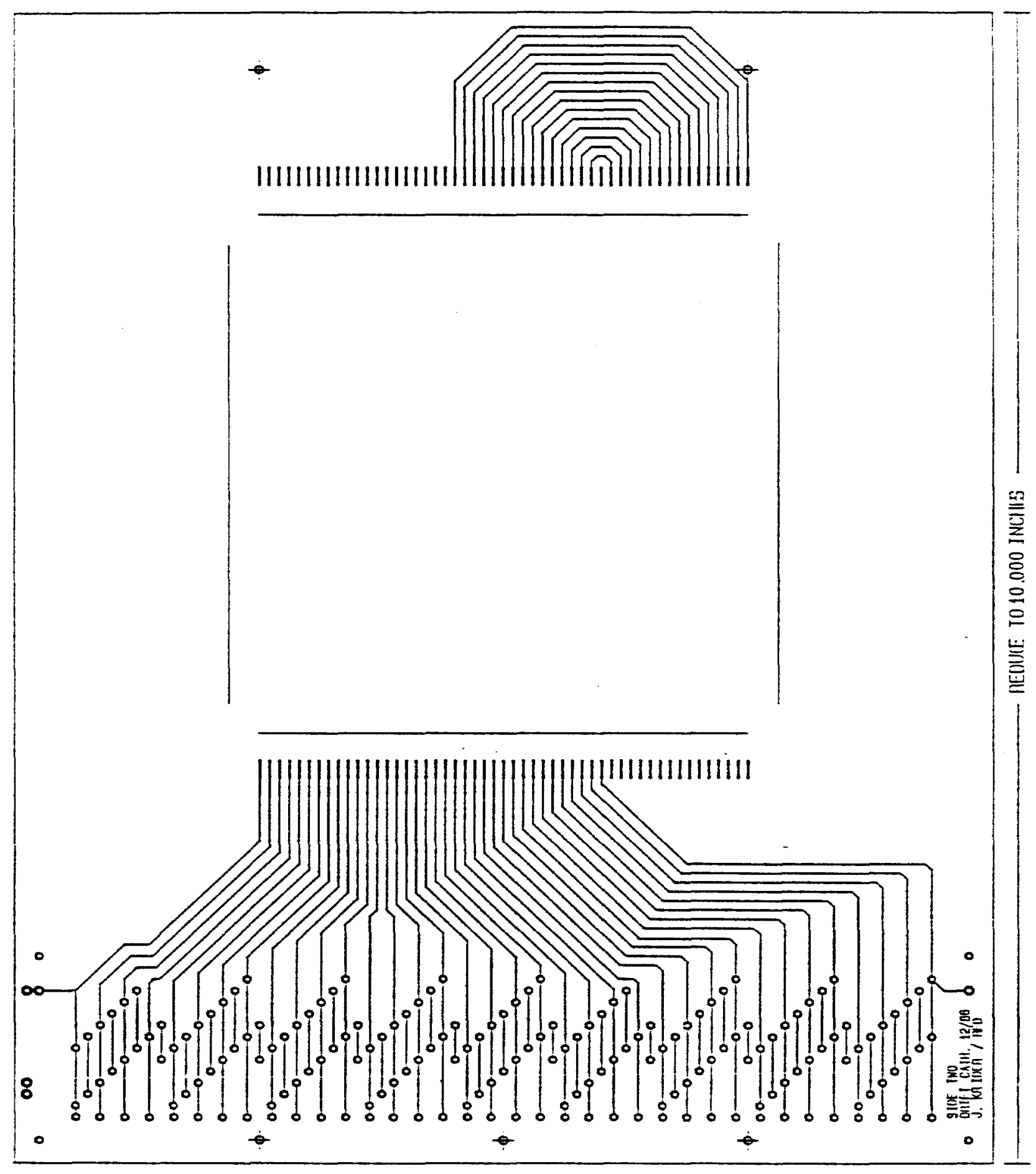


Figure 4. Circuit diagram for one cell

\section{Cathode HV}

(negative)

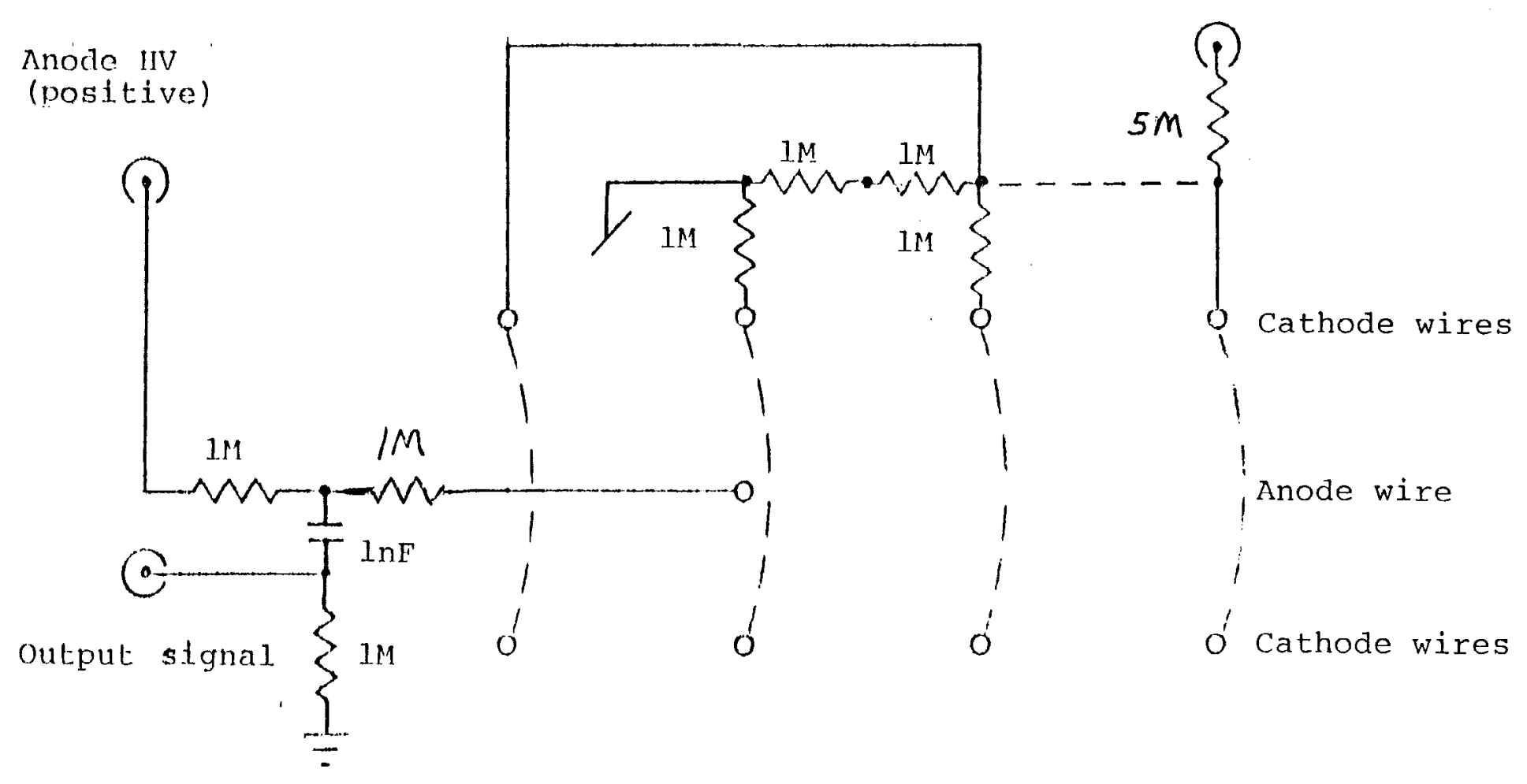


Figure 5. Chamber amplifier schematic

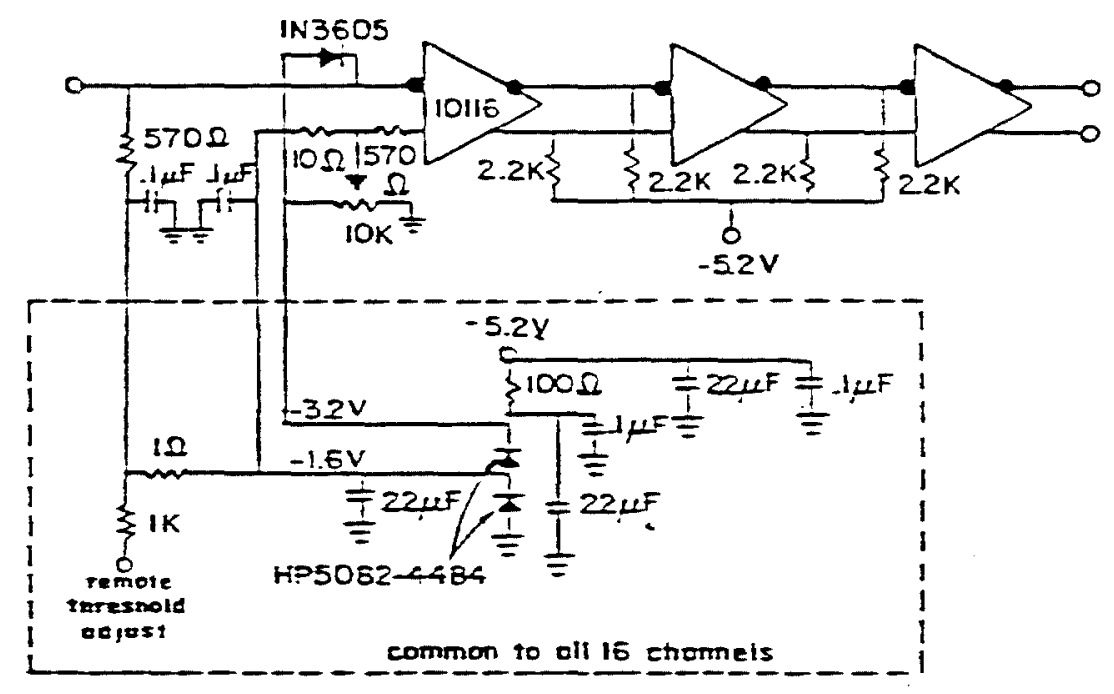


Figure 6.

IV Amplifier Time Slewing

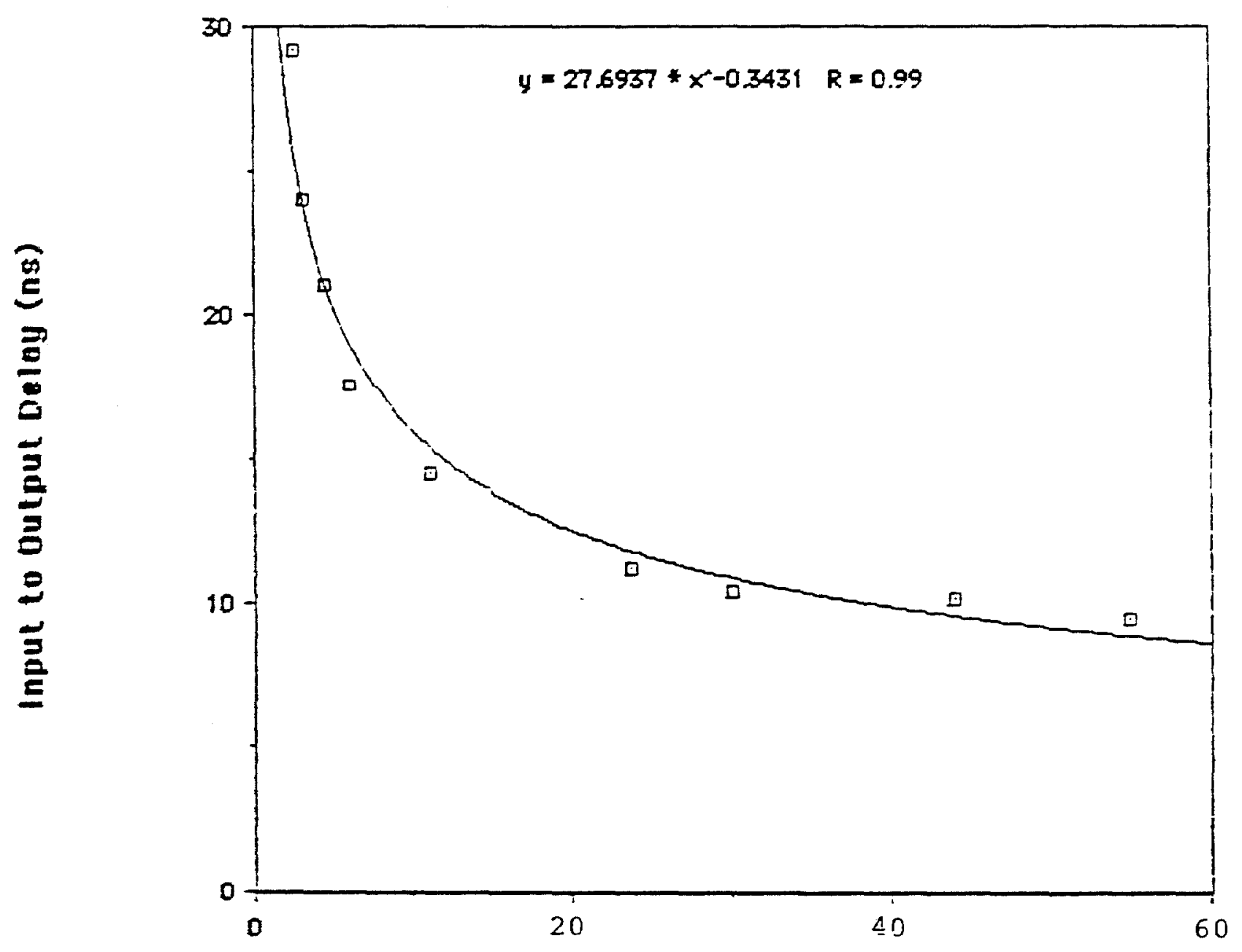

Input Signal (UA) 
Figure 7a. Time slewing for signals at the plateau edge
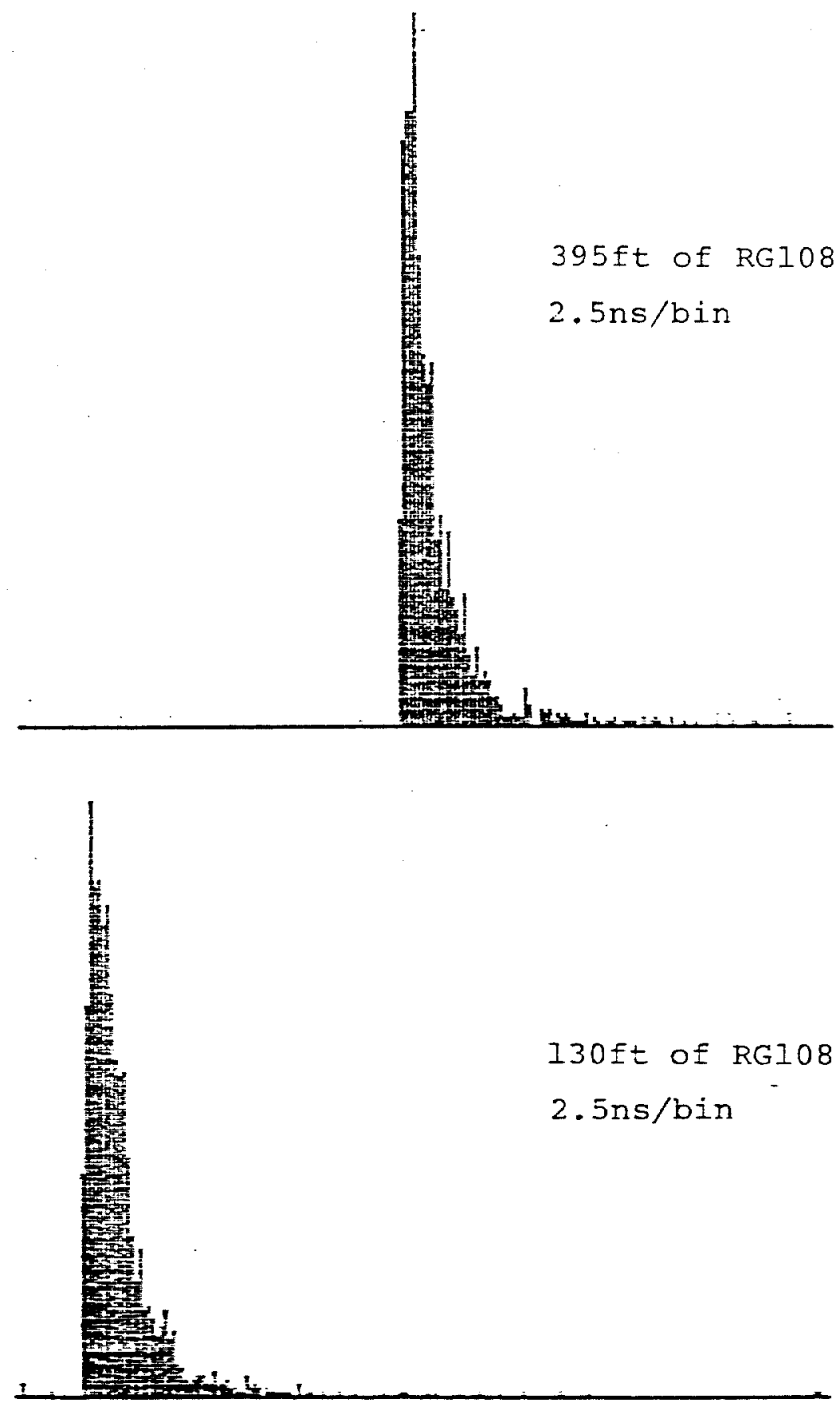
Figure 7b. Time slewing loov onto the plateau

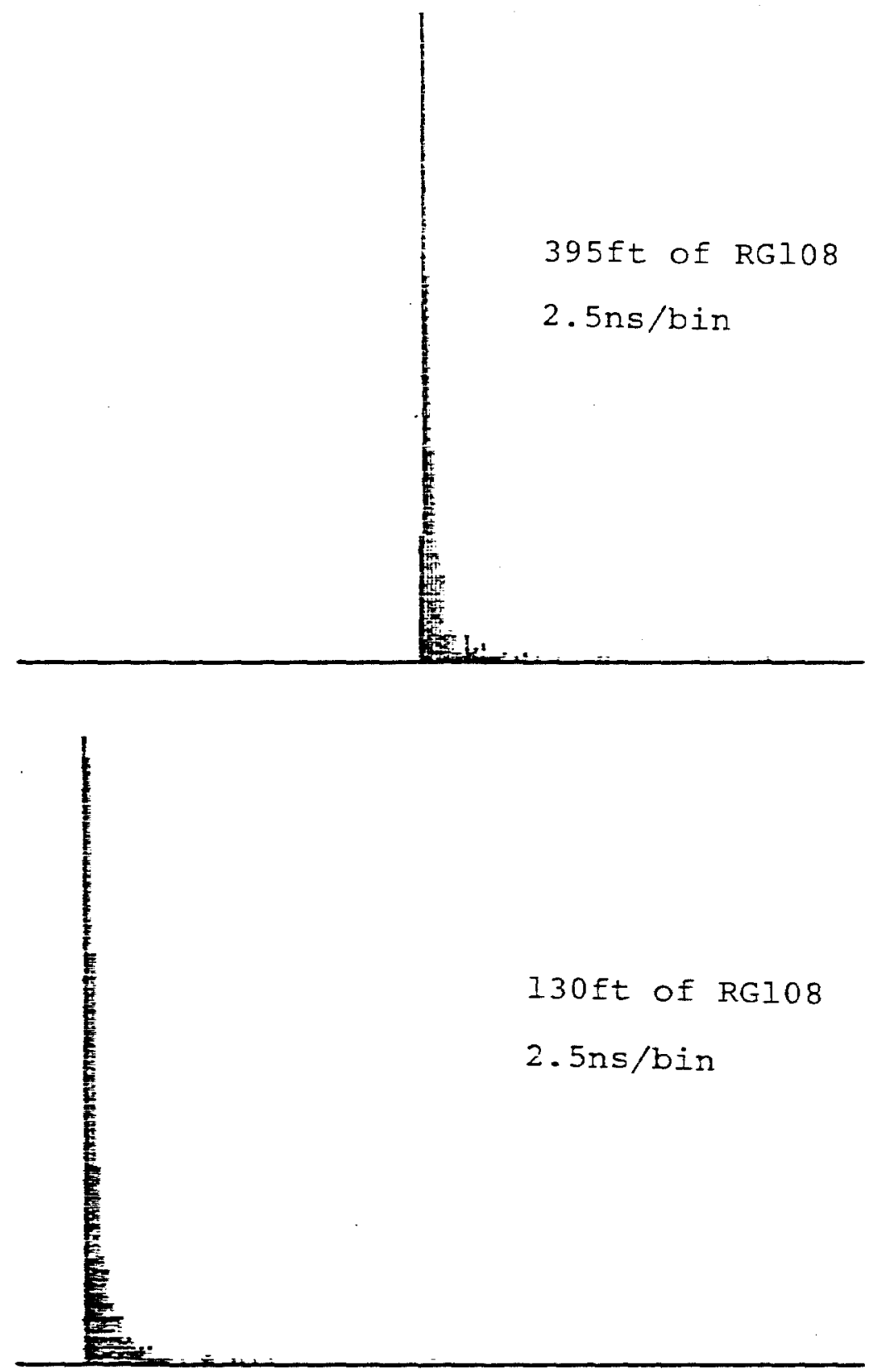




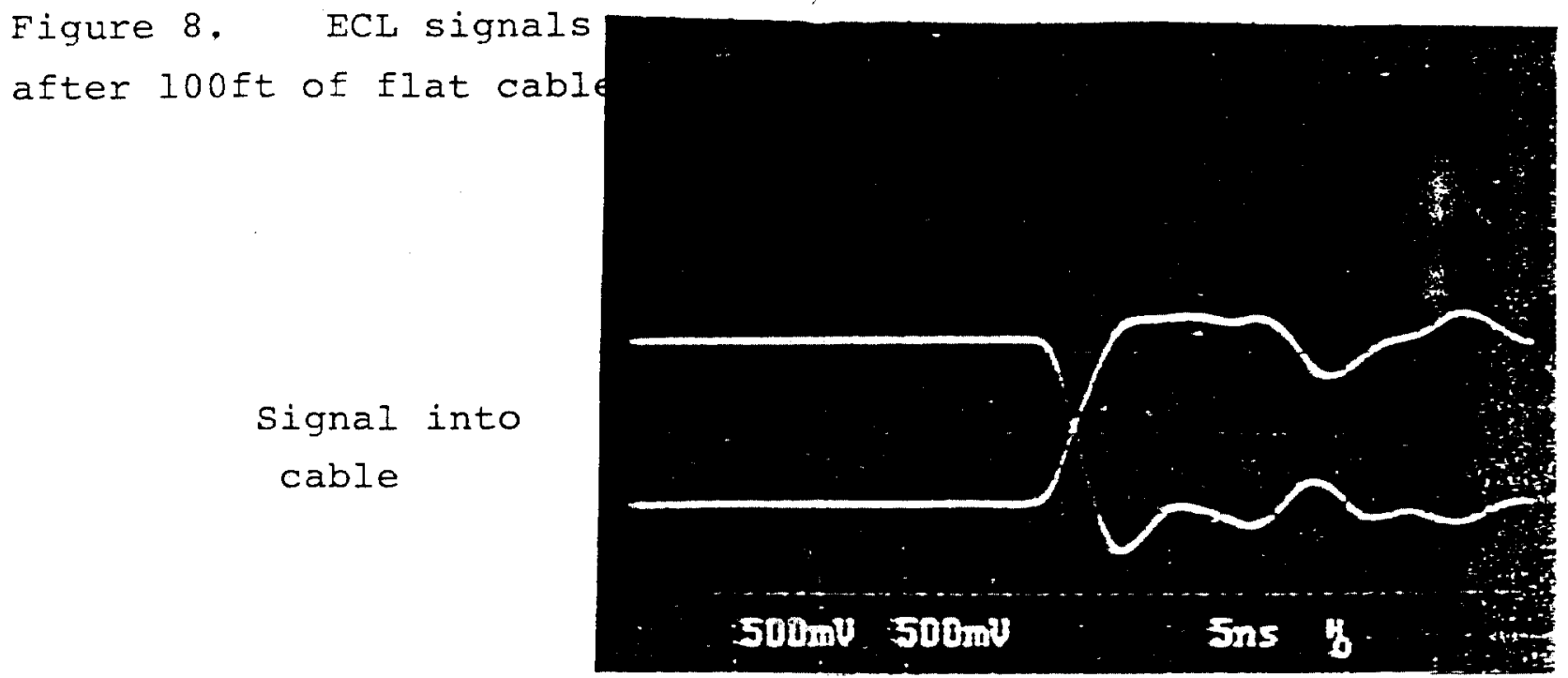

Cable output $50 \mathrm{~ns} / \mathrm{div}$

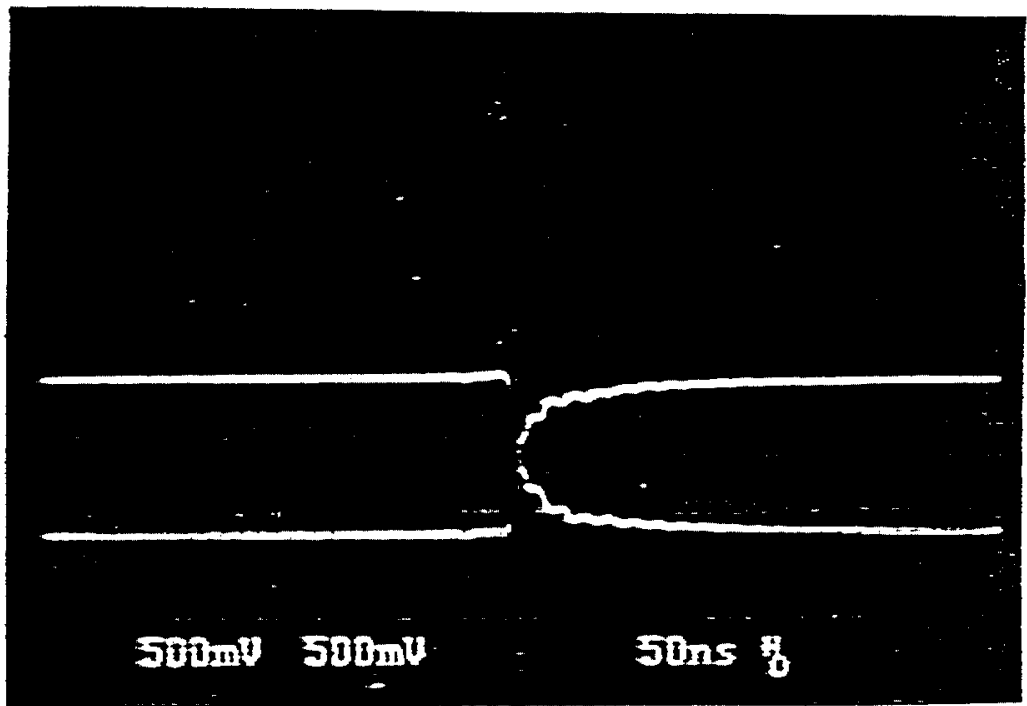

Cable output $50 n s / d i v$

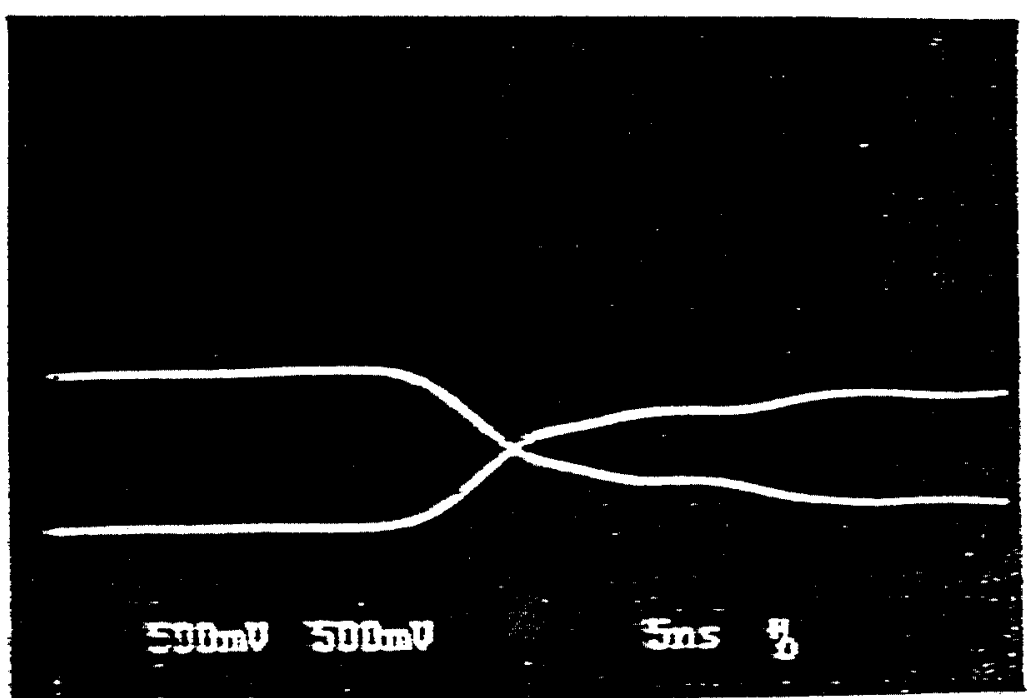


Figure 9.

\section{Drift Error for 100mV Noise vs. Coble Length}

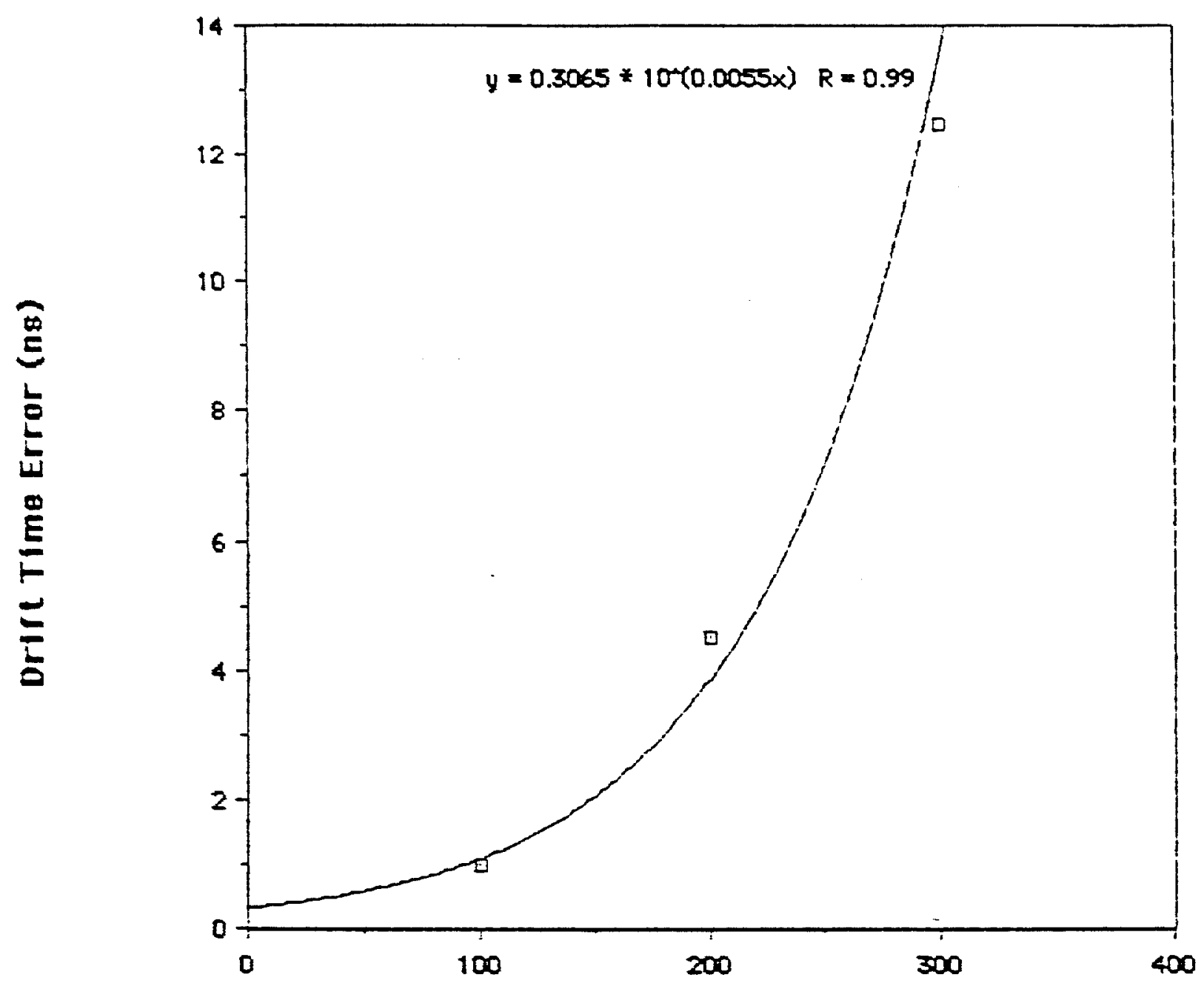

Cable length (ft) 
Figure 10a. Rul06 signals after looft of flat cable

At plateau edge

(1517V)

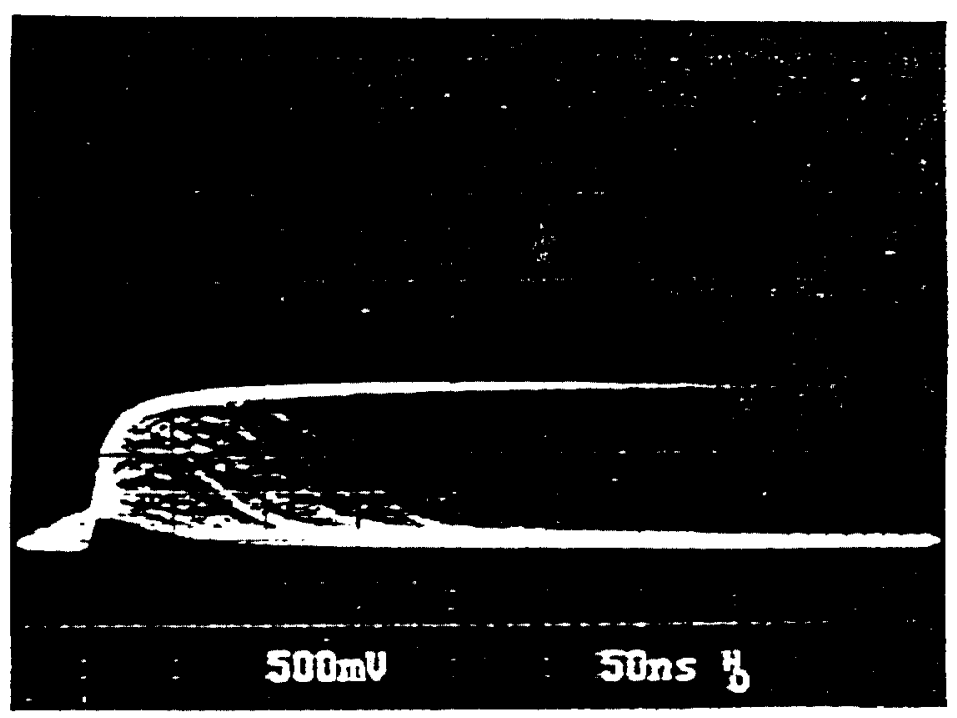

$100 v$ onto plateau

(I620V)

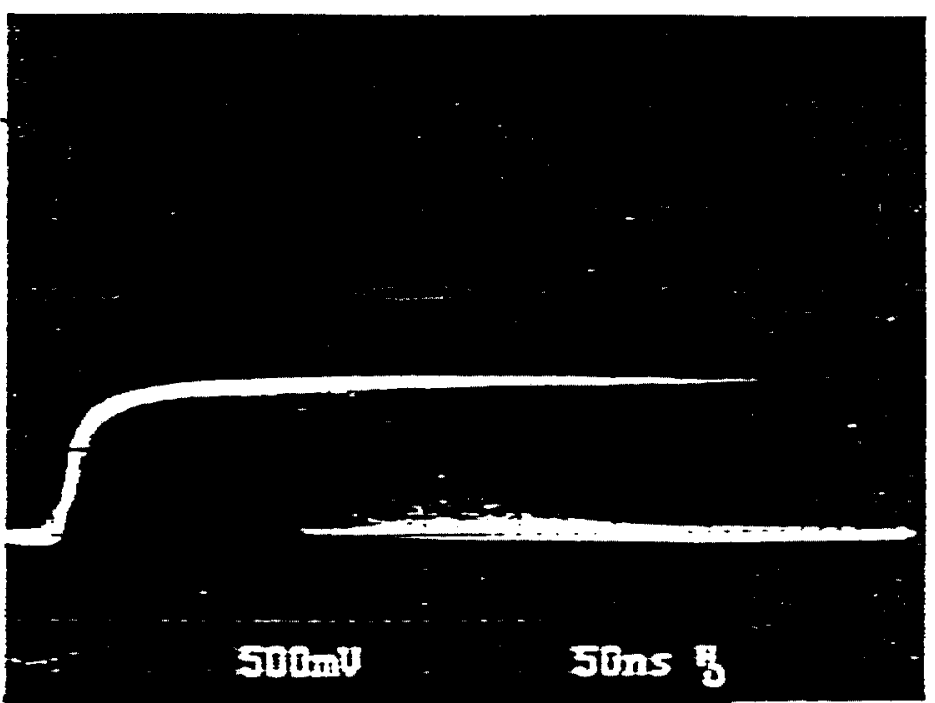


Figure 10b. Fe55 signals after lo0ft of flat cable

\section{A1 - गु9 0}

At $1517 \mathrm{~V}$

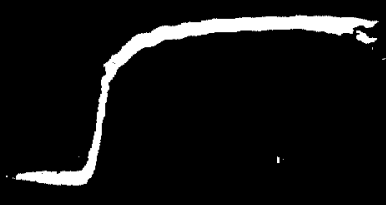

$500 \mathrm{ny}$

Sins 8

At $1620 \mathrm{~V}$

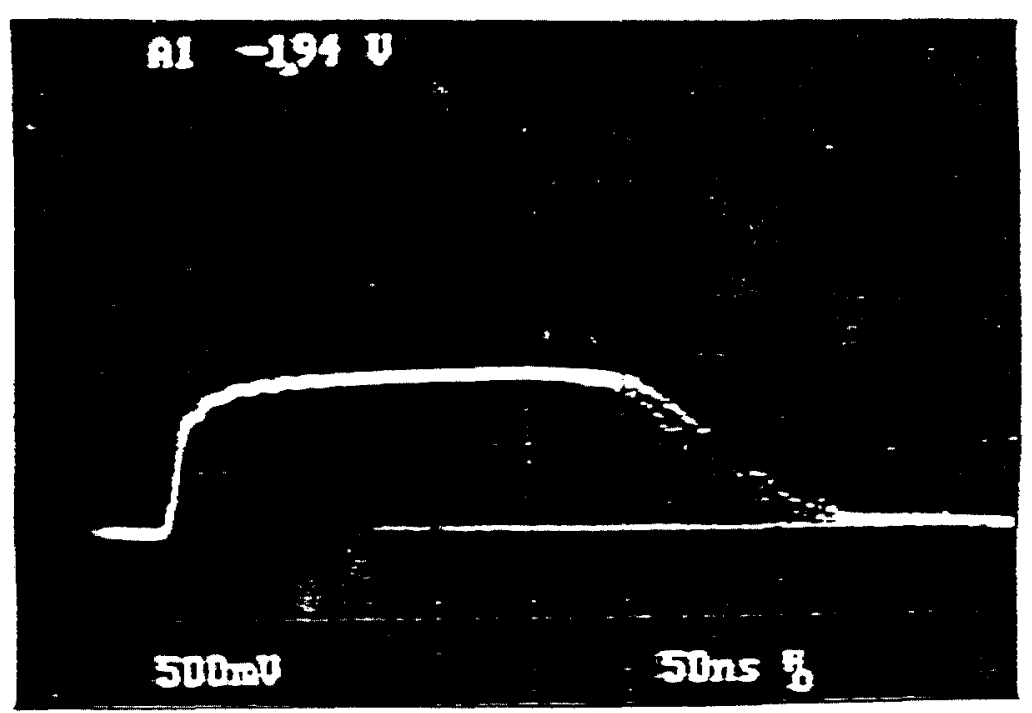


Figure 11. Efficiency and drift time measurement setup

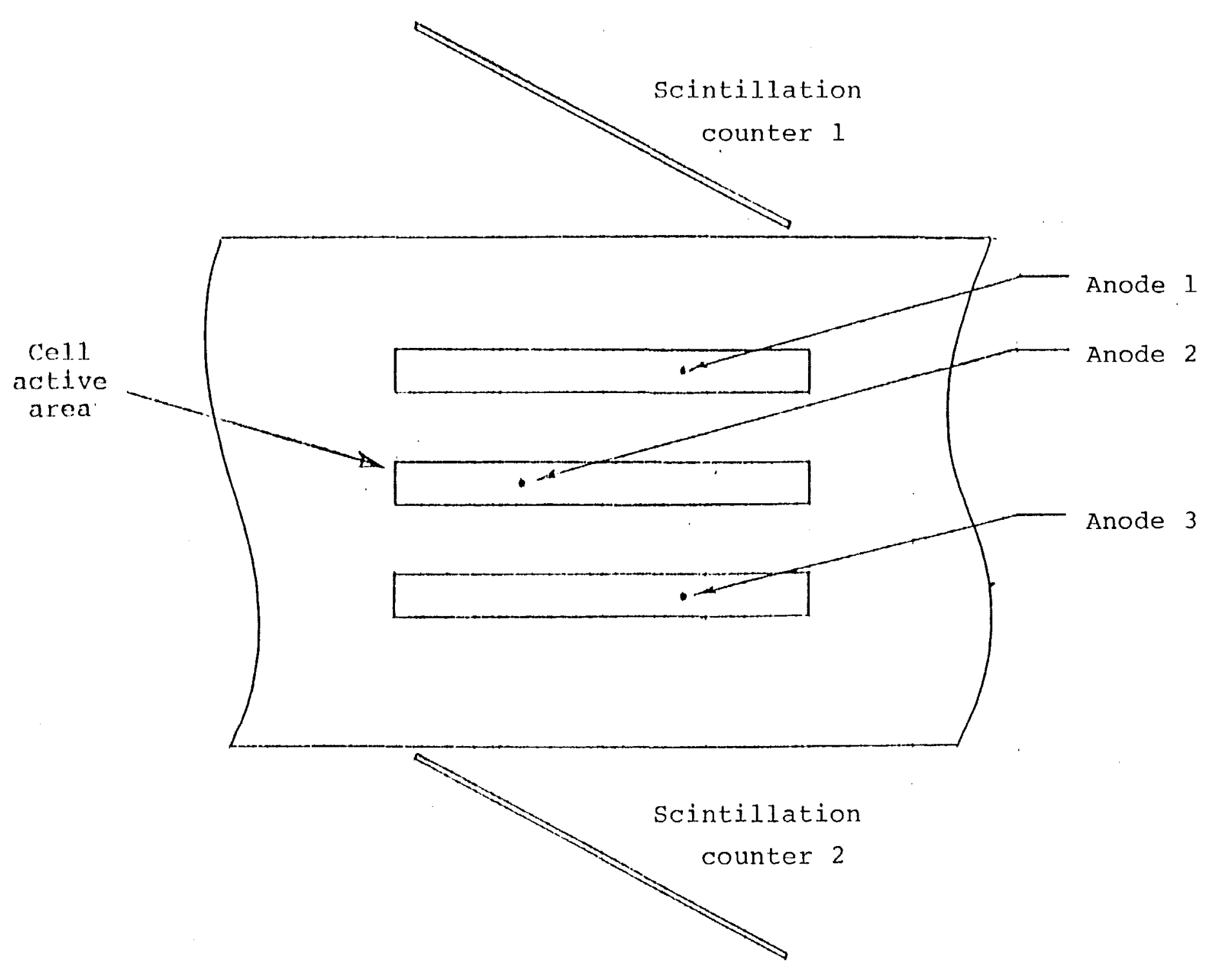


Figure 12.

Chamber Gain vs, High Voltage

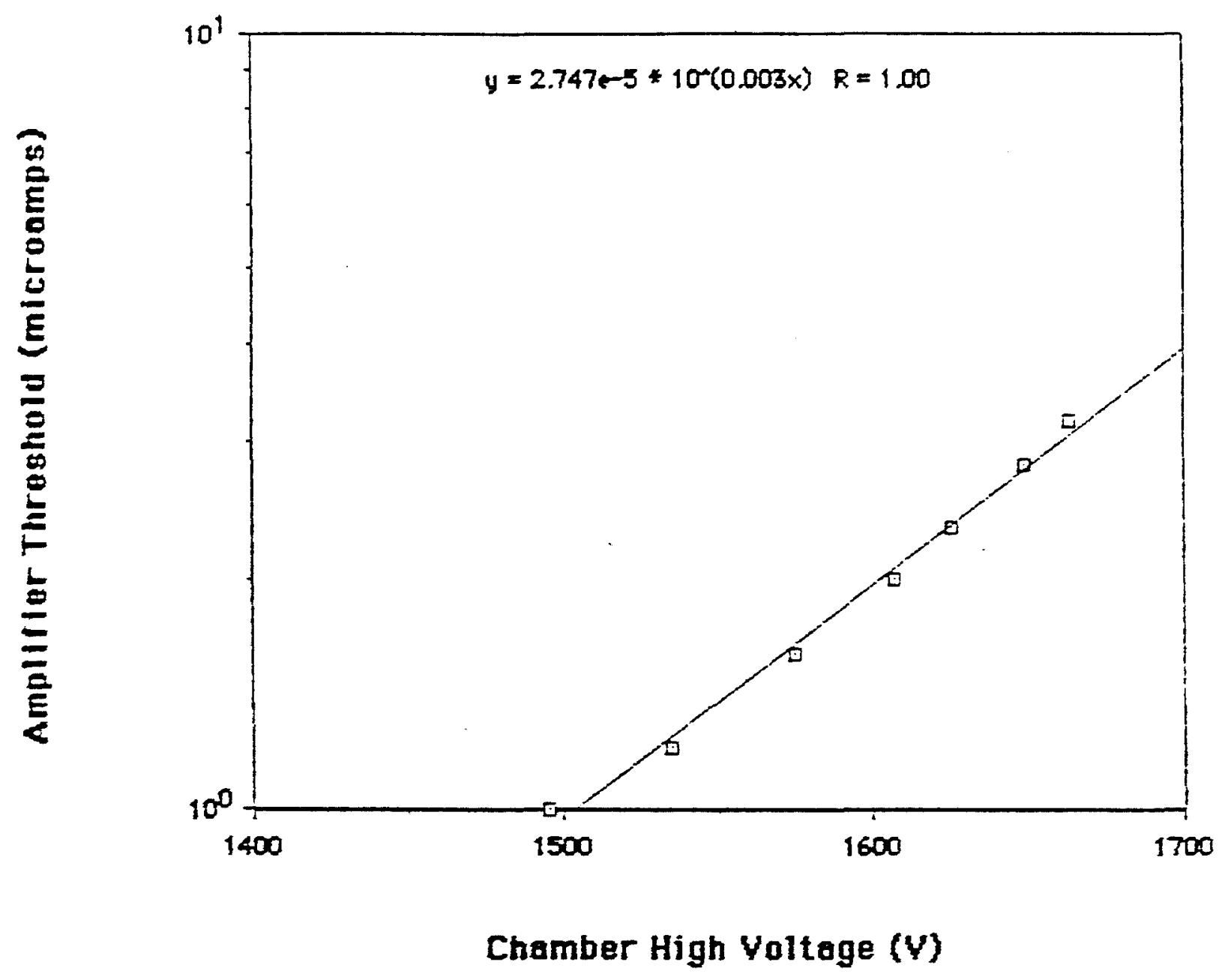


Figure 13.

Efficiency us. High Voltage

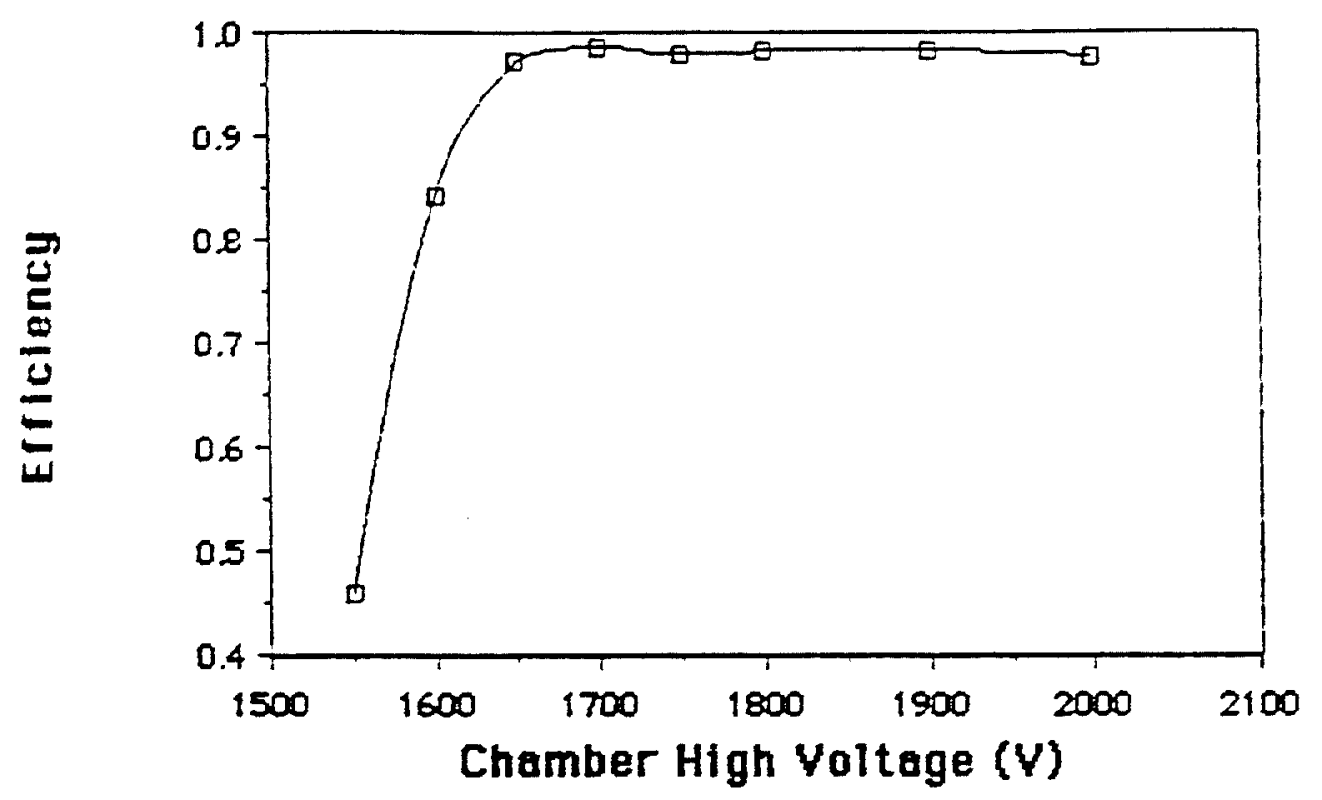

Anade Singles ys. High Voltage
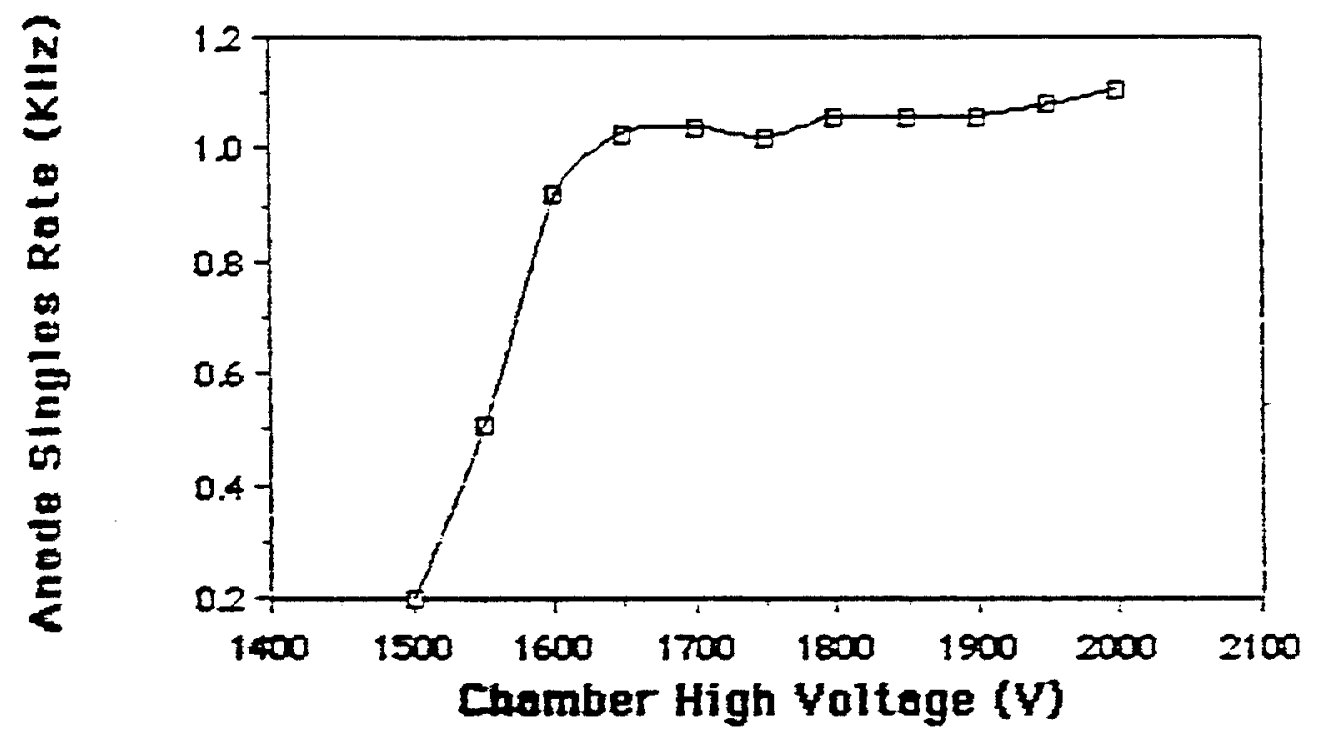
Figure 14.

Drift Velocity ys. Electric Field

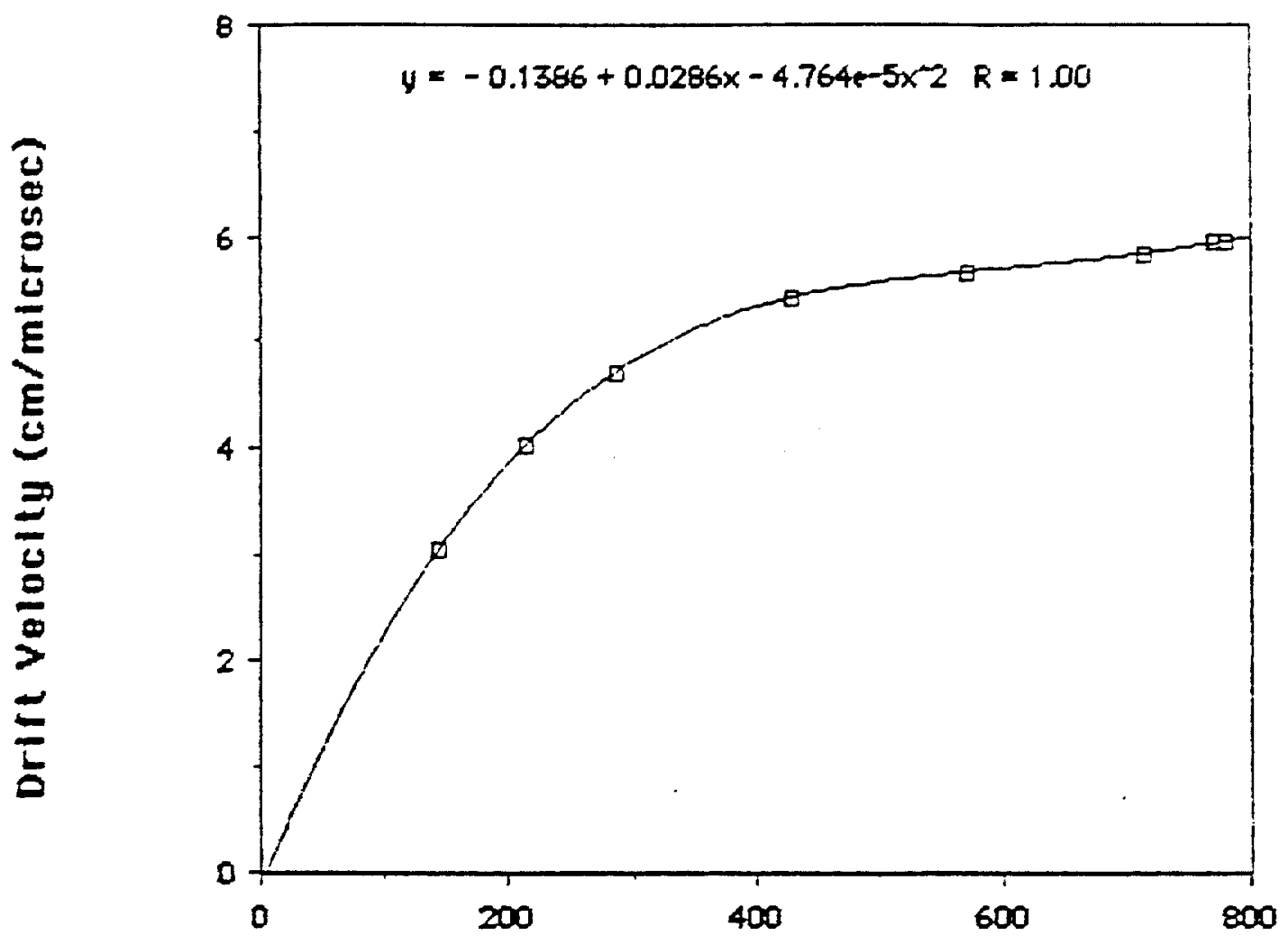

Electric Field ( $Y / \mathrm{cm}$ ) 
Figure 15. Drift time spectrum for an entire cell

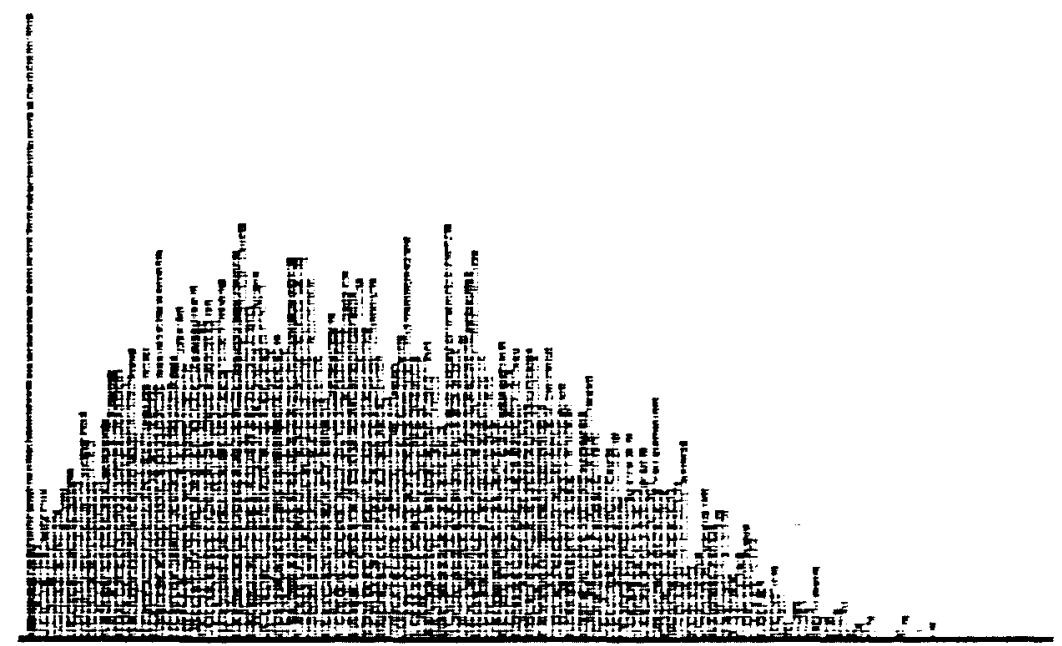

$2.5 \mathrm{~ns} / \mathrm{bin}$ 
Figure 16. Drift velocity in argon - ethane (linearity)

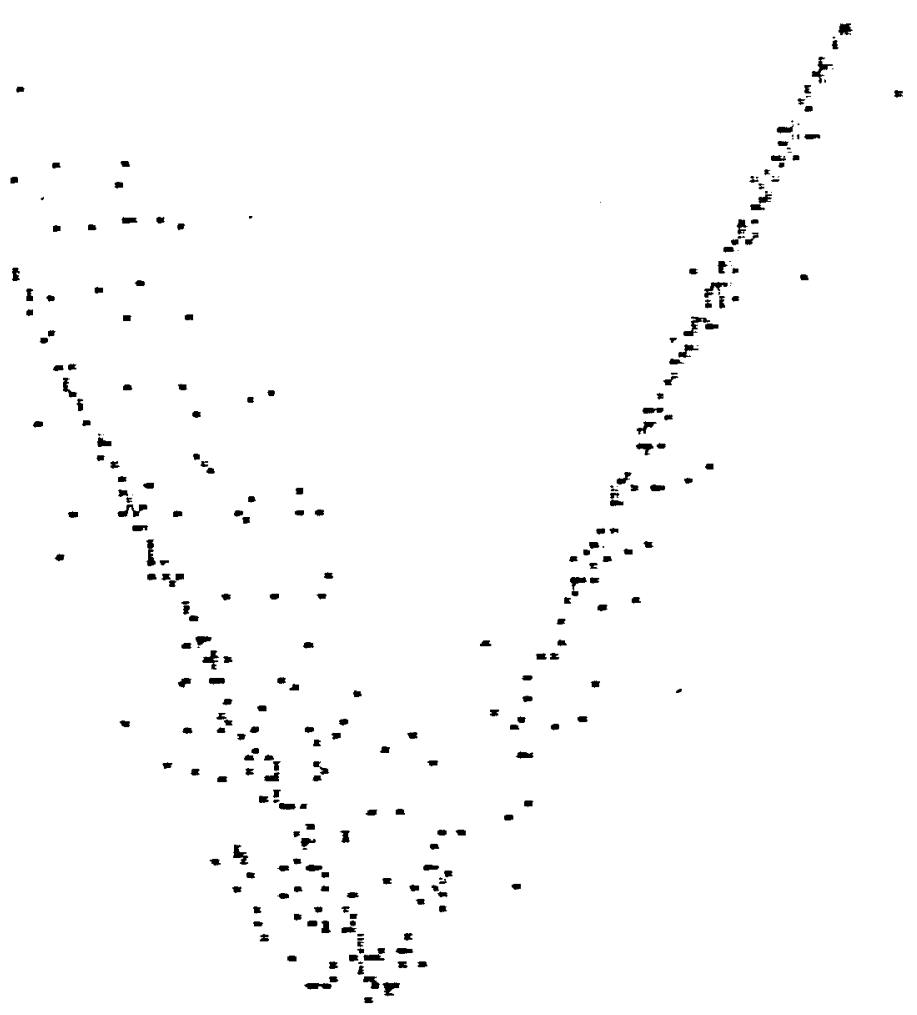


Figure 17. Drift velocity in argon - $\mathrm{CO}_{2}$ (linearity)

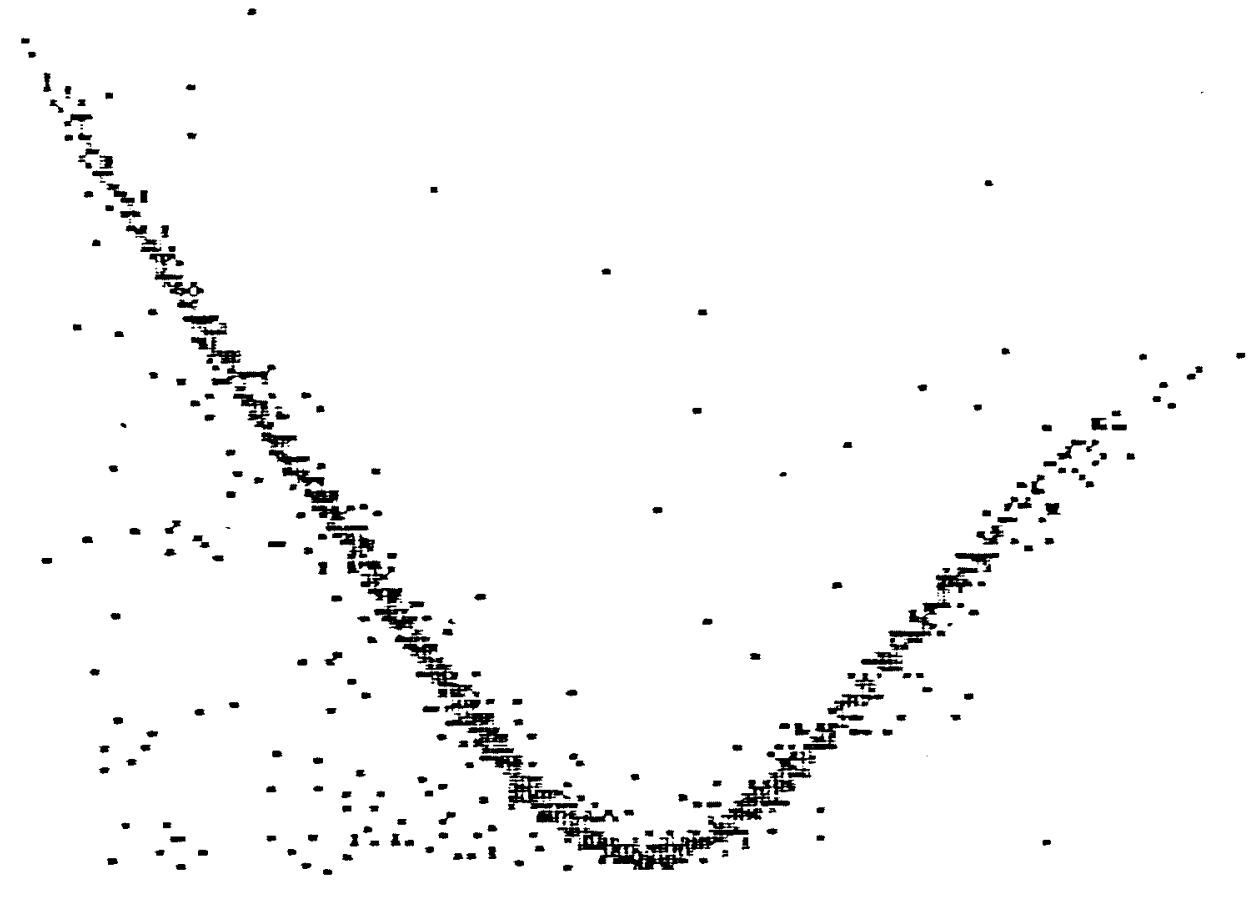




\section{Figure 18. Global time resolution: cosmic rays through argon - ethane}

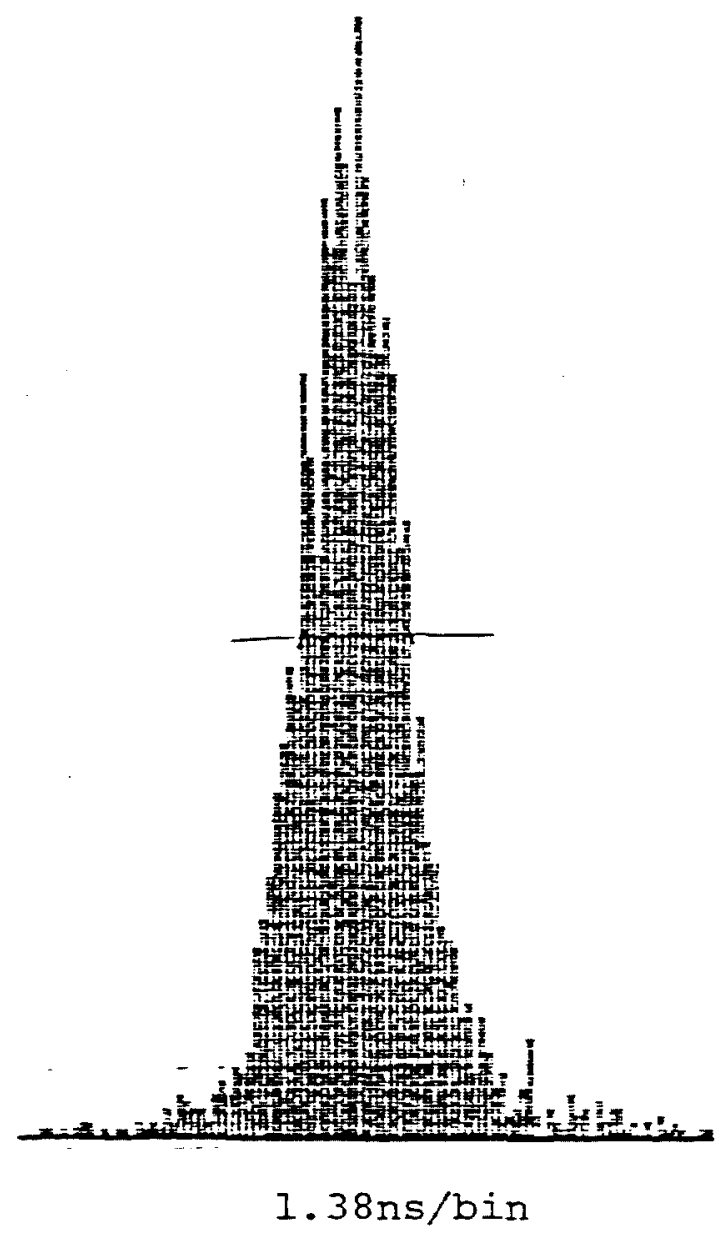


Figure 19. Global time resolution: cosmic rays through argon $-\mathrm{CO}_{2}$

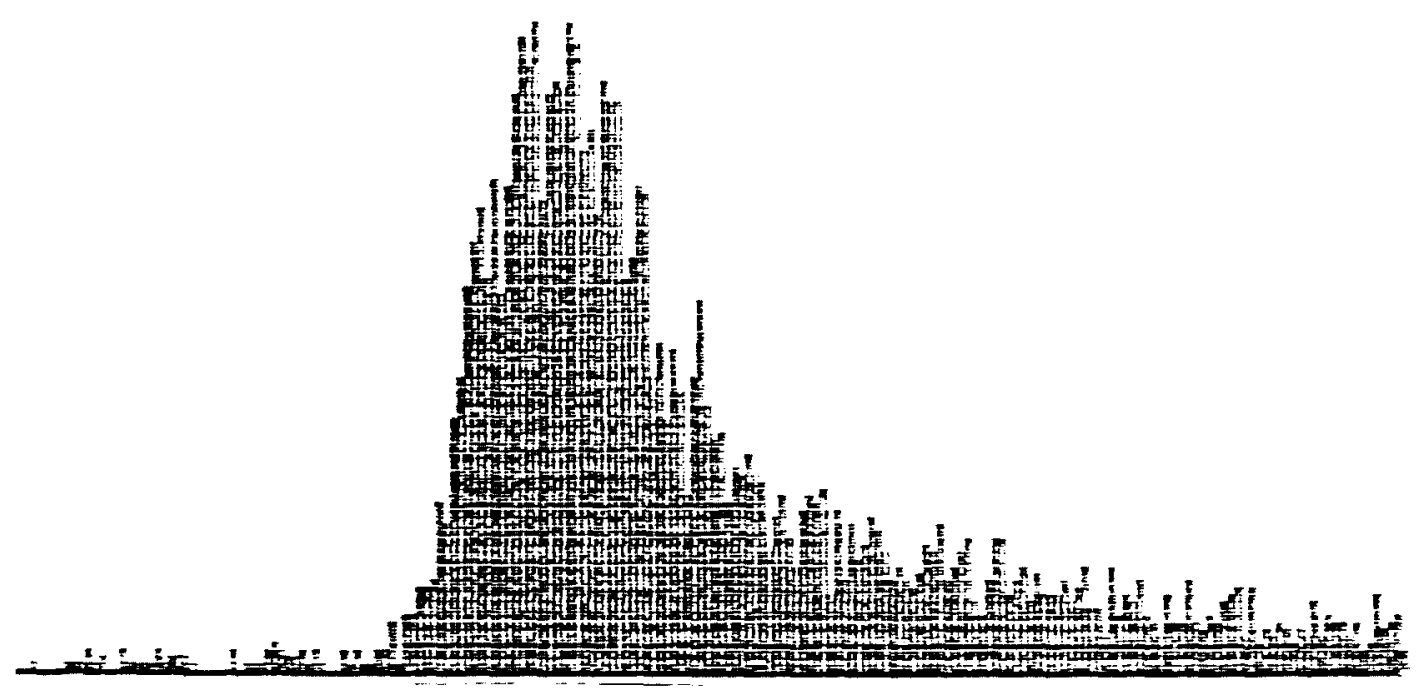

$2.5 \mathrm{~ns} / \mathrm{bin}$ 
Figure 20. Time resolution at one point: Rul06 tracks through argon $-\mathrm{CO}_{2}$

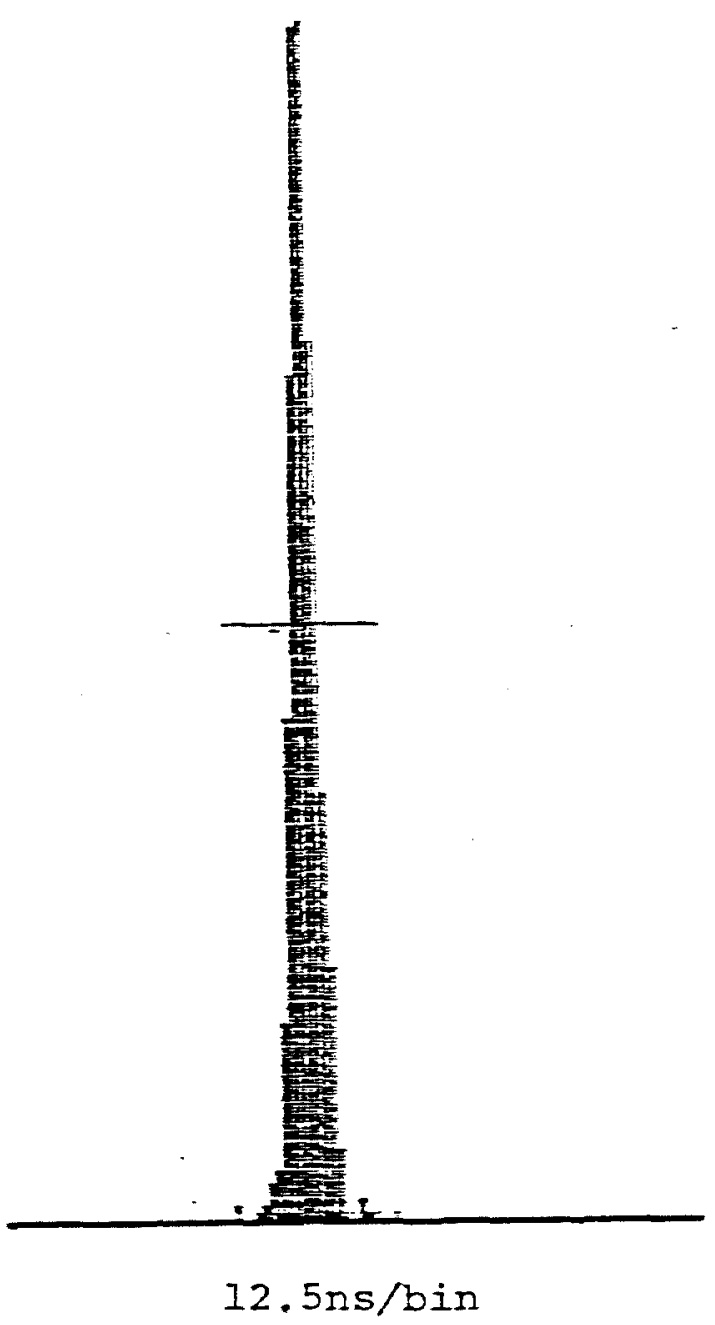


Difference in

Figure 21. Electron drift time vs. distance from midplane

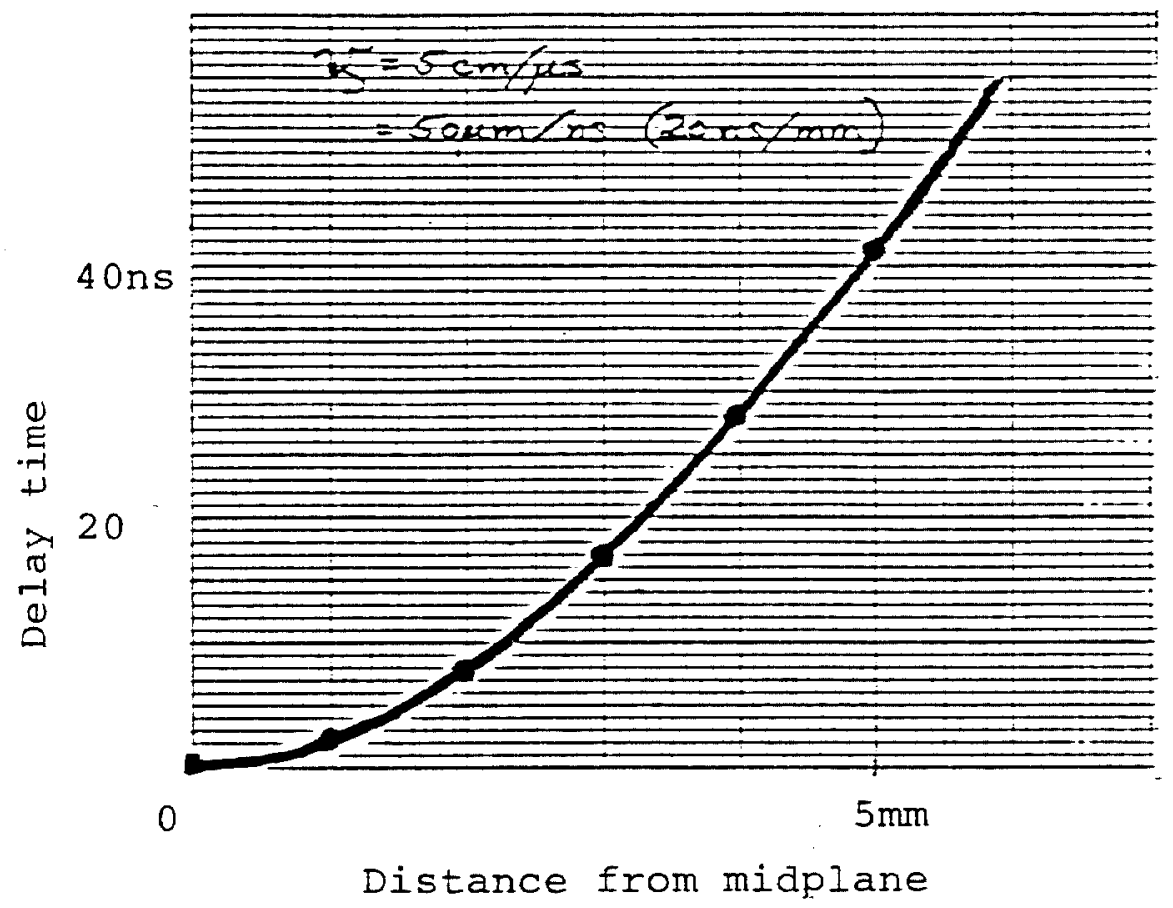




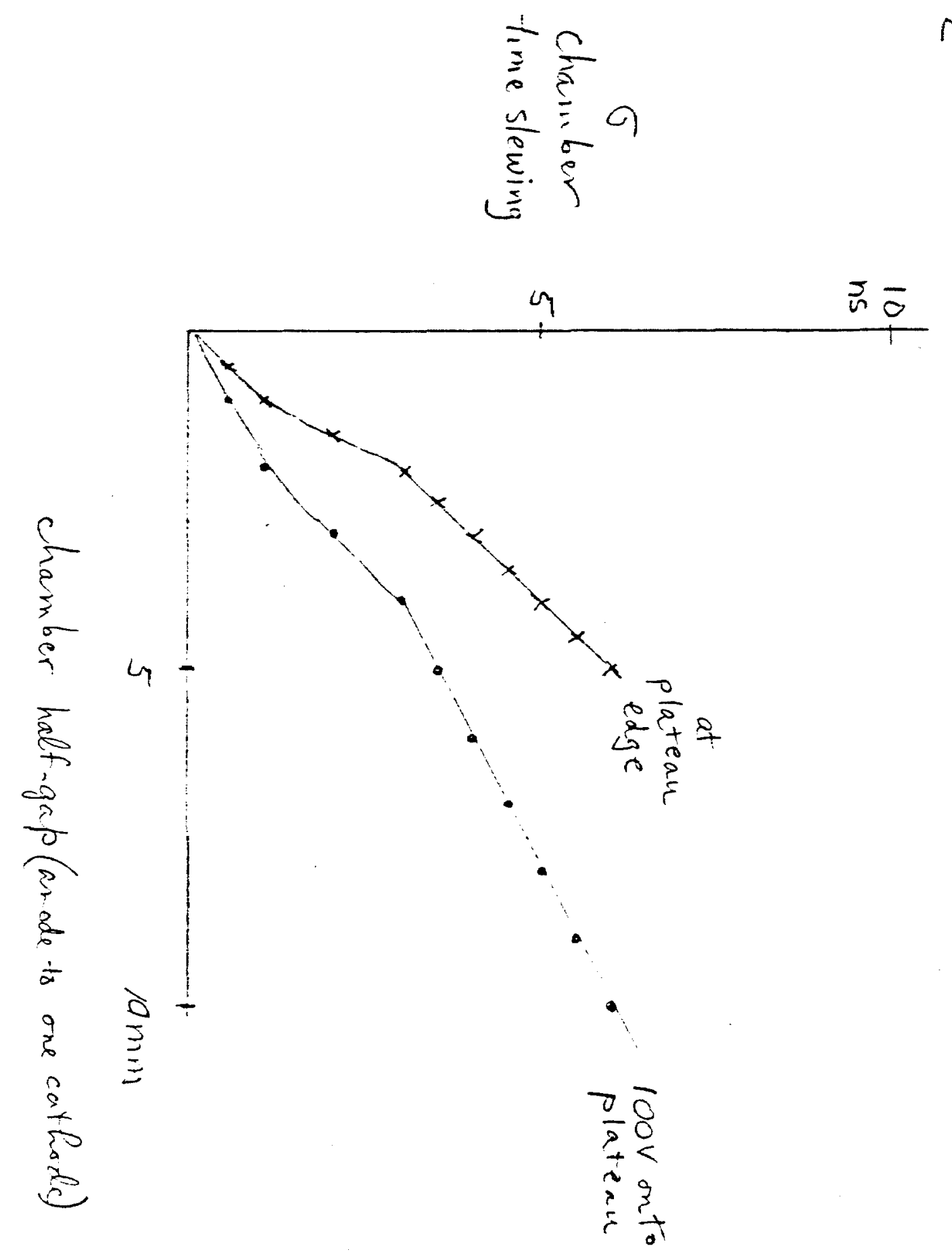

$\frac{1}{3}$ 